\title{
A study to assess the gynecological problems among adolescent girls attending gynecology out patient department in secondary care hospital in North East India
}

\author{
Reetika Joshi *, Veino Kuveio Duomai
}

Department of Obstetrics and Gynecology, Baptist Christian Hospital, Tezpur, Assam, India

Received: 18 October 2020

Accepted: 04 January 2021

*Correspondence:

Dr. Reetika Joshi,

E-mail: deepak.ji.joshi@gmail.com

Copyright: (c) the author(s), publisher and licensee Medip Academy. This is an open-access article distributed under the terms of the Creative Commons Attribution Non-Commercial License, which permits unrestricted non-commercial use, distribution, and reproduction in any medium, provided the original work is properly cited.

\begin{abstract}
Background: Adolescence is a period of transition between childhood and adulthood. It is marked by enormous biological, physical and psychological changes. The young girls are embarrassed to discuss their gynecolgical problems and are hesitant to seek medical help, however their problems need to be identified and addressed. This study identifies the major health problems faced by adolescent girls.

Methods: This research study was conducted at Baptist Christian hospital, Assam from Oct 2019 to Mar 2020. A total of 61 adolescent girls in the age group of 10 to 19 years attending gynecology out patient department of Baptist Christian hospital, Assam were included in this study.

Results: Most of the girls who attended the OPD were between 17 to 19 years of age (54\%). Maximum number $(75 \%)$ of girls attain menarche at the mean age of 12.6 years. $55.7 \%$ of girls presented with menstrual disorders and the most common menstrual disorder was found to be menorrhagia (32\%), followed by oligomenorrhea (29\%).

Conclusions: This study gives out that young girls must be taught to take care of their body and they must be made aware of their bodily changes during growing up years. Health education regarding menstrual hygiene, menstrual problems and reproductive health should be imparted to them.
\end{abstract}

Keywords: Adolescence, Menstrual disorders, Gynecological problems, Adolescent health

\section{INTRODUCTION}

Adolescence is a period of transition between childhood and adulthood. It is marked by enormous biological, physical and psychological changes. WHO defines adolescent age group between 10 to 19 years. ${ }^{1}$ About $21 \%$ of Indian population is adolescent which is largest in the world. ${ }^{2}$ Gynecological problems in adolescent girls are unique and also has psychological bearing on their young minds. The young girls are embarrassed to discuss their gynecolgical problems and are hesitant to seek medical help. This study was undertaken to review the gynecolgical problems of adolescent girls attending gynecological out-patient department.

\section{METHODS}

This prospective observational study was conducted for a period of 6 months from Oct 2019 to Mar 2020. Ethical clearance was accorded by the hospital authorities and all necessary support was also extended.

\section{Inclusion criteria}

Girls starting from 10 years of age and up to 19 years of age were only considered for this prospective observational study. A total of 61 adolescent girls of age group 10 to 19 years attending gynecology out patient department of Baptist Christian hospital, Assam between Oct 2019 to Mar 2020 were included in this study. A 
detailed history was taken of all the adolescent girls. The general physical examination including height, weight, BMI, secondary sexual character, spine and thyroid examination was carried out. The per abdomen and examination of external genitalia was conducted. The investigations included blood grouping and $\mathrm{Rh}$ typing, complete blood count, blood sugar, urine routine, coagulogram, hormonal assay (LH, FSH, prolactin, $\mathrm{TSH}$ ), ultrasonography of whole abdomen and pelvis, contrast tomography (when required).

\section{Exclusion criteria}

Adolescent girls with known chronic disorders like tuberculosis, diabetes, cancer, anatomical malformation and psychiatric illness were not included in this study.

\section{Statistical analysis}

The data was carefully categorised for various age groups and then analysed using Microsoft excel to keep the entire study simple. For better assessment of the patients and problems presented by them, percentages were obtained using simple mathematical formulae.

\section{RESULTS}

\section{Age distribution}

Most of the girls belong to 17 to 19 years of age i.e., 33 girls $(54 \%)$ followed by 14 to 16 years i.e., 17 girls $(28 \%)$.

Table 1: Age distribution among participants

\begin{tabular}{|lll|}
\hline Age (years) & Number & Percentage (\%) \\
\hline $\mathbf{1 0 - 1 3}$ & 11 & 18.03 \\
\hline $\mathbf{1 4 - 1 6}$ & 17 & 27.87 \\
\hline $\mathbf{1 7 - 1 9}$ & 33 & 54.10 \\
\hline Total & 61 & 100 \\
\hline
\end{tabular}

\section{Body mass index}

10 participants were excluded being antenatal. 36 girls (70.59\%) had normal BMI, 23.5\% had low BMI, only $5.8 \%$ of the participants were overweight.

Table 2: BMI distribution among participants.

\begin{tabular}{|lll|}
\hline BMI $\left(\mathrm{kg} / \mathrm{m}^{2}\right)$ & Number & Percentage $(\%)$ \\
\hline $\mathbf{1 9}$ & 12 & 23.53 \\
\hline $\mathbf{1 9 - 2 5}$ & 36 & 70.59 \\
\hline$>\mathbf{2 5}$ & 3 & 5.88 \\
\hline Total & 51 & 100 \\
\hline
\end{tabular}

\section{Marital status}

47 girls $(77 \%)$ were unmarried whereas 14 girls $(23 \%)$ were married.
Table 3: Marital status among participants.

\begin{tabular}{|lll|}
\hline Marital status & Number & Percentage (\%) \\
\hline Unmarried & 47 & 77 \\
\hline Married & 14 & 23 \\
\hline Total & 61 & 100 \\
\hline
\end{tabular}

\section{Age of menarche}

Majority of the girls attained menarche between the age of 11 to 13 years. Two girls attained menarche before the age of 11, and two girls did not attain menarche till the age of 16 years.

Table 4: Distribution of participants according to age of menarche.

\begin{tabular}{|lll|}
\hline $\begin{array}{l}\text { Age of menarche } \\
\text { (year) }\end{array}$ & Number & Percentage $(\%)$ \\
\hline$<\mathbf{1 1}$ & 2 & 3.28 \\
\hline $\mathbf{1 1 - 1 3}$ & 46 & 75.40 \\
\hline $\mathbf{1 4 - 1 6}$ & 11 & 18.03 \\
\hline No menarche & 2 & 3.28 \\
\hline Total & 61 & 100 \\
\hline
\end{tabular}

\section{Gynecological problems}

$55.7 \%$ (34) girls had presented with menstrual disorders. $16 \%$ (10) girls were antenatal, followed by ovarian tumour in $4.9 \%$ (3) of girls.

Table 5: Distribution of gynecological problems observed among participants.

\begin{tabular}{|lll|}
\hline $\begin{array}{l}\text { Gynaecological } \\
\text { problems }\end{array}$ & Numbers & Percentage $(\%)$ \\
\hline Menstrual disorders & 34 & 55.8 \\
\hline Primary amenorrhea & 1 & 1.7 \\
\hline Ovarian tumour & 3 & 4.9 \\
\hline Vaginal discharge & 4 & 6.6 \\
\hline UTI & 2 & 3.2 \\
\hline Perineal abscess & 1 & 1.7 \\
\hline Hymenal injury & 1 & 1.7 \\
\hline Mastalgia & 1 & 1.7 \\
\hline Antenatal & 10 & 16. \\
\hline Postnatal & 4 & 6.7 \\
\hline Total & 61 & 100 \\
\hline
\end{tabular}

\section{Types of menstrual disorders}

Out of 34 girls presented with different menstrual disorders, 32\% had Menorrhagia, 29\% Oligomenorrhea, $20.5 \%$ with dysmenorrhea followed by $17.6 \%$ had secondary amenorrhea.

\section{Causes of irregular cycles}

Majority of the girls i.e., $44.4 \%$ had dysfunctional uterine bleeding (DUB) followed by $29.6 \%$ had PCOD 
and hypothyroidism was observed in $11.1 \%$ girls. 2 girls were diagnosed with abdominal Koch's. One case each of immune thrombocytopenia and ovarian malignancy was found.

Table 6: Types of menstrual disorders observed among participants.

\begin{tabular}{|lll|}
\hline Menstrual disorder & Numbers & Percentage (\%) \\
\hline Menorrhagia & 11 & 32 \\
\hline Oligomenorrhea & 10 & 29 \\
\hline Dysmenorrhea & 7 & 20.5 \\
\hline $\begin{array}{l}\text { Secondary } \\
\text { amenorrhea }\end{array}$ & 6 & 17.6 \\
\hline Total & 34 & 100 \\
\hline
\end{tabular}

Table 7: Distribution according to the causes of irregular cycles.

\begin{tabular}{|lll|}
\hline $\begin{array}{l}\text { Causes of irregular } \\
\text { cycle }\end{array}$ & Number & Percentage $(\%)$ \\
\hline DUB & 12 & 44.4 \\
\hline PCOD & 8 & 29.7 \\
\hline ITP & 1 & 3.7 \\
\hline Abdominal Koch's & 2 & 7.4 \\
\hline Ovarian malignancy & 1 & 3.7 \\
\hline Hypothyroidism & 3 & 11.1 \\
\hline Total & 27 & 100 \\
\hline
\end{tabular}

\section{Distribution according to anaemia}

34 girls $(55.7 \%)$ had mild anaemia and $22.9 \%$ were moderately anaemic. Only 13 girls (21.3\%) had haemoglobin more than $12 \mathrm{gm}$ percent. None of the girls had severe anaemia.

Table 8: Distribution of participants according to the haemoglobin content.

\begin{tabular}{|lll|}
\hline Anaemia & Number & Percentage (\%) \\
\hline$>$ 12 & 13 & 21.5 \\
\hline Mild (10-11.9) & 34 & 55.7 \\
\hline Moderate (7-9.9) & 14 & 22.9 \\
\hline Severe (<7) & - & - \\
\hline Total & 61 & 100 \\
\hline
\end{tabular}

\section{DISCUSSION}

The present study shows that among the adolescent girls attending gynecology OPD, $54 \%$ of girls were in the age group of 17-19 years. It is comparable to the study conducted by Goswami et al and Chandarkala et al. ${ }^{3,4}$ $75 \%$ of girls attained menarche between the age group of $10-13$ years with mean age of 12.6 years. Similar results were seen in the study conducted by Chandarkala and Dasgupta et al.,
In the present study $77 \%$ girls were unmarried and $23 \%$ were married, it is comparable to the study conducted by Chandarkala et al in which $24 \%$ adolescent girls were married. ${ }^{4}$ In the study by Goswami et al only $13.3 \%$ girls were married. $^{3}$ In our study $70 \%$ girls had normal BMI and only $5.8 \%$ were overweight. Whereas, $22 \%$ girls were overweight in study by Chandarkala et al. ${ }^{4}$ In the study by Goswami et al $10.6 \%$ adolescents were overweight. $^{3}$

In the present study, $55.7 \%$ of the adolescents presented with menstrual disorders, similar results were obtained in studies conducted by Kumar $(50.7 \%)$ and Goswami et al $(58.06 \%) .{ }^{6,7}$ In a study by Jagannath et al $76.5 \%$ of the adolescents presented with menstrual disorders. ${ }^{8}$

In our study the most common menstrual disorder was menorrhagia, found in $32 \%$ of girls. This result was similar to studies by Goswami et al (33.3\%) and Jagannath et al (33.3\%). ${ }^{3,8}$ In the present study $29 \%$ girls had Oligomenorrhea which is more in comparison to studies by Jagannath et al $(20.7 \%)$ and Chandarkala et al $(10 \%){ }^{8,4}$

In the present study $20 \%$ of girls presented with dysmenorrhea which is comparable to the results seen in study by Jagannath et al $(19.8 \%)$ and more in comparison to the study by Chandarkala et al $(8 \%){ }^{8,4}$ The main cause of irregular cycles in present study was dysfunctional uterine bleeding (44.4\%) followed by PCOD in $29.6 \%$ and hypothyroidism in $11.1 \%$. In the study by Jagannath et al $67 \%$ of girls had DUB followed by $13 \%$ had PCOD and $10.8 \%$ had hypothyroidism. ${ }^{8}$ The incidence of PCOD was more in our study. In our study $55.7 \%$ girls had mild anaemia and comparable results were obtained in study conducted by Chandrakumari et al. ${ }^{9}$

\section{Limitations}

Since this study was conducted in a rural secondary care center with a small sample size and of north-east Indian population only, hence the accuracy of result estimates may be limited. Larger studies are required to be carried out over varying strata of Indian population to definitely identify the different gynaecological problems among adolescent girls.

\section{CONCLUSION}

Adolescents are the future of any country. We should take care of our young girls and teach them to be confident about their bodily changes during growing up years. Health education regarding menstrual hygiene, menstrual problems and reproductive health should be imparted to them. A social change regarding early marriage in rural set up will help in reduction in complications associated with teenage pregnancies.

At hospitals the adolescent gynecological problems should be dealt in dedicated clinics. Such clinics should 
provide friendly and empathetic environment along with proper counselling.

\section{ACKNOWLEDGMENTS}

We would like to thank the department of obstetrics and gynecology at Baptist Christian hospital, Tezpur, Assam for their support and cooperation of patients and their families admitted to this hospital.

\section{Funding: No funding sources}

Conflict of interest: None declared

Ethical approval: The study was approved by the Institutional Ethics Committee

\section{REFERENCES}

1. Hanson M, Gluckman P. Evolution: Development and timing of puberty. Trends Endocrinal metab. 2006;17(1):7-12.

2. Rashtriya Kishor Swasthya Karyakram. Strategy Handbook. Adolescent. Health Division Ministry of Health and Family Welfare Government of India. 2014;27-163.

3. Goswami P, Ahirwar G, Mishra P, Agarwal V. Adolescent Gynaecological problems: A Prospective Study. J Evolution Med Dental Sci. 2015;4(102):16709-12.
4. Chandrakala G, Patruni M. Study to assess gynaecological problems in adolescent girls attending the gynaecology OPD at a private teaching institute, Telangana state, South India. Int J Clin Obstet Gynaecol. 2020;4(2):221-4.

5. Dasgupta A, Sarkar M. Menstrual hygiene: How hygienic is the adolescent girl? Indian J Community Med. 2008;33:77-80.

6. Kumar A, Verma A, Mittal S. Gynaecological Disorders in girls less than 20 years of age. J obstet Gynaecol India. 1998;48(1):60-3.

7. Goswami S, Dutta R, Sen Gupta S. A profile of adolescent girls with Gynaecological problem. J Obstet Gynaecol India. 1990;55(4):353-5.

8. Jagannath P, Prasad DB, Kumar BM. Evaluation of Gynaecological Problems Among Adolscent Girls Attending Gynaecology Out Patient Department in Gauhati Medical College and Hospital. Sch J App Med Sci. 2015;3(7D):2729-32.

9. Chandrakumari AS, Sinha A, Singaravelu S, Jaikumar S. Prevalence of Anemia Among Adolescent Girls in a Rural Area of Tamil Nadu, India. J Family Med Primary Care. 2019;8:1414-7.

Cite this article as: Joshi R, Duomai VK. A study to assess the gynecological problems among adolescent girls attending gynecology out patient department in secondary care hospital in North East India. Int J Reprod Contracept Obstet Gynecol 2021;10:546-9. 